\title{
Cell Sources for Human In vitro Bone Models
}

\author{
Sana Ansari ${ }^{1} \cdot$ Keita Ito $^{1} \cdot$ Sandra Hofmann ${ }^{1}$ (D) \\ Accepted: 16 December 2020 / Published online: 15 January 2021 \\ (C) The Author(s) 2021
}

\begin{abstract}
Purpose of Review One aim in bone tissue engineering is to develop human cell-based, 3D in vitro bone models to study bone physiology and pathology. Due to the heterogeneity of cells among patients, patient's own cells are needed to be obtained, ideally, from one single cell source. This review attempts to identify the appropriate cell sources for development of such models. Recent Findings Bone marrow and peripheral blood are considered as suitable sources for extraction of osteoblast/osteocyte and osteoclast progenitor cells. Recent studies on these cell sources have shown no significant differences between isolated progenitor cells. However, various parameters such as medium composition affect the cell's proliferation and differentiation potential which could make the peripheral blood-derived stem cells superior to the ones from bone marrow.

Summary Peripheral blood can be considered a suitable source for osteoblast/osteocyte and osteoclast progenitor cells, being less invasive for the patient. However, more investigations are needed focusing on extraction and differentiation of both cell types from the same donor sample of peripheral blood.
\end{abstract}

Keywords Invitrobonemodel $\cdot$ Bonemarrow $\cdot$ Peripheralblood $\cdot$ Mesenchymal stemcell $\cdot$ Hematopoietic stem cell $\cdot$ Personalized medicine

\section{Introduction}

Bone is a complex multifunctional organ that sustains the integrity of the vertebrate skeleton, provides mechanical support for locomotion, protects internal organs, and acts as a mineral storage [1]. Throughout life, bone tissue continuously undergoes a physiological process called bone remodeling to adapt to environmental changes, repair old and damaged bone, and maintain its shape and strength. Bone remodeling occurs via balanced activities of its specialized cells which are tightly regulated and controlled through biochemical pathways [2]. In vivo, bone remodeling is composed of four consecutive phases: recruitment and activation of mononuclear progenitor cells, resorption of the organic and inorganic matrix of bone by mature osteoclasts, preparation of the resorbed surface of matrix deposition, and deposition of new bone by osteoblasts $[1,3]$.

This article is part of the Topical Collection on Osteocytes

Sandra Hofmann

S.Hofmann@tue.nl

1 Orthopaedic Biomechanics, Department of Biomedical Engineering and Institute for Complex Molecular Systems, Eindhoven University of Technology, P.O. Box 513, 5600 MB Eindhoven, the Netherlands

\section{Bone Cells}

\section{Osteoblasts}

Osteoblasts are bone-forming cells derived from mesenchymal stem cells (MSCs). MSCs differentiate towards osteoblasts under appropriate mechanical and/or biochemical stimuli $[4,5]$. Osteoblasts are responsible to produce the organic matrix of bone extracellular matrix composed of mainly collagen type I and a small percentage of non-collagenous proteins (NCPs) [6]. Moreover, they are involved in inorganic matrix deposition through mechanisms in which NCPs play important roles [7, 8]. At the end of the bone-forming phase, osteoblasts can have one of the following fates: become embedded in the mineralized matrix and differentiate towards osteocytes, transform into inactive bone-lining cells, or undergo apoptosis (Fig. 1) [9].

\section{Osteocytes}

Osteocytes as terminally differentiated osteoblasts form $95 \%$ of the cellular component of bone; thus, they are the most abundant bone cell type [10]. During bone formation, a large portion of osteoblasts becomes embedded in the mineralized 


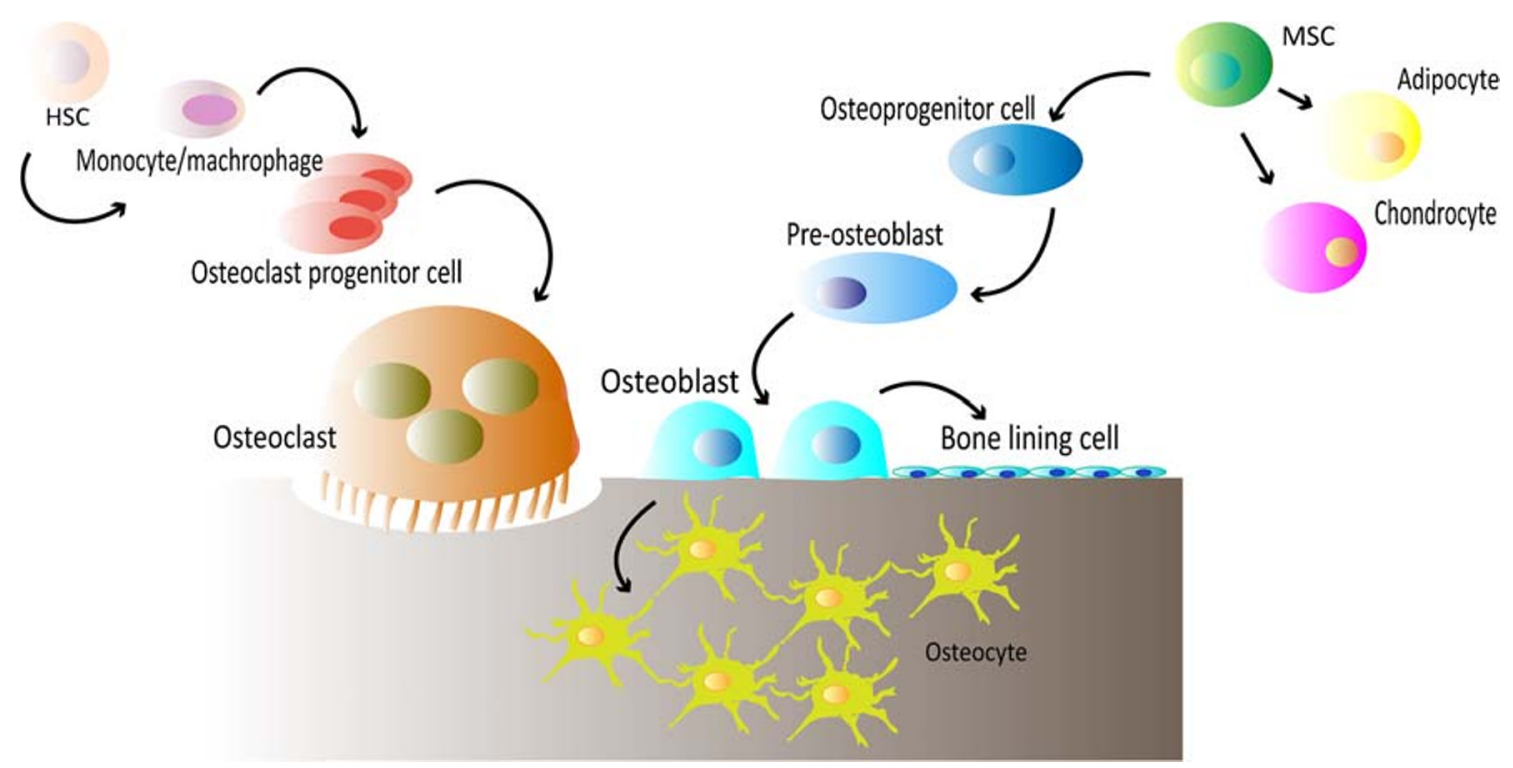

Fig. 1 Bone progenitor cells and their differentiation into osteoblasts/osteocytes and osteoclasts

matrix, decrease their cell body volume, and attain a stellar shape morphology with long processes which form a network with their neighboring cells and cells on the bone surface [10]. These cells are thought to orchestrate the activities of bone formation and resorption by translating mechanical loading into biochemical signals $[11,12]$.

\section{Osteoclasts}

Osteoclasts are bone-resorbing cells that dissolve the inorganic matrix and enzymatically degrade extracellular matrix proteins by secreting acid and lytic enzymes [13]. These cells are large, multinucleated cells originating from the monocyte/ macrophage lineage which differentiate from hematopoietic stem cells (HSCs) (Fig. 1). These stem cells are situated in bone marrow and can be mobilized into the peripheral blood [14]. Osteoclast differentiation and activation are thought to be regulated by neighboring stromal cells and osteoblasts [15].

\section{Others}

Besides the cell types that are involved in bone remodeling process, bone consists of other cell types which are less known to have a direct role in the bone remodeling process; they will not be addressed in this review. These cells are for example bone-lining cells, which are inactive osteoblasts at the end of the bone formation phase, chondrocytes, and endothelial and perivascular cells due to the vascularized nature of bone tissue $[10,16,17]$.

\section{Bone Metabolic Diseases}

Disturbing the bone remodeling process results in the development of metabolic bone diseases including osteoporosis characterized by an altered bone turnover balance as a result of high osteoclast activity and impaired bone formation. Osteoporosis is the most common bone metabolic disease. It is characterized by decreased bone strength and increased bone fracture risk [18, 19]. Apart from osteoporosis, there are more diseases related to an impaired bone remodeling process including osteopetrosis, Paget's disease, renal osteodystrophy, and rickets. They are less prevalent, which limits our current knowledge on their pathology and their efficient treatment [20]. Thus, the development of in vitro models that mimic bone-related pathologies could enhance the understanding of these diseases and the design of more efficient treatments.

\section{The Need for Personalized In Vitro Models}

The current gold standard in developing novel treatments for bone pathologies and pre-clinical drug screening is using animal models. However, these often fail to represent human conditions due to interspecies differences in physiology [21, 22]. Moreover, the need for indicating the appropriate species to model a specific disease, ethical concerns due to genetic mutations and/or nutrient deficiency to induce the disease and high costs of maintenance limit the use of animals as models and thus our knowledge on specific bone metabolic diseases. Animal models often result in poor translation of pre-clinical studies to human clinical trials and promising new treatments 
might fail prior to clinical testing [22-24]. The development of new therapies requires an in-depth and detailed understanding of bone physiology and pathology and how the different cells are affected in their interaction. Over the past few years, bone tissue engineering techniques have been applied to create $3 \mathrm{D}$ in vitro bone models based on human cells that can be used as an alternative to in vivo models $[18,23]$. These in vitro bone models require the (co-)culture of the specific bone cells to work closely together under physiological conditions. Because there is a large cell heterogeneity among patients and their diverse characteristics caused by diseases include changes in cell receptors, there is a need to use patientspecific cells for personalized in vitro bone models [19, 25]. Thus, in order to represent the patient's bone biological system, representative in vitro models require the patient's own cells. The ideal and efficient way to achieve this approach is to isolate progenitor cells of osteoblasts and osteoclasts with high efficiency, to expand them in vitro, and to differentiate them towards osteoblasts/osteocytes and osteoclasts, respectively, ideally from one cell source with minimal invasiveness for the patient (i.e., either from peripheral blood or from bone marrow).

This review attempts the following: to (a) briefly identify what kind of cells can be used for bone-related studies, (b) explain the importance of progenitor cells as the most promising cell types for developing in vitro bone models, (c) discuss bone marrow and peripheral blood as sources to obtain both osteoblasts/osteocytes and osteoclasts progenitor cells, and (d) finally, the isolation method, proliferation capacity, and differentiation potential of progenitor cells from bone marrow and peripheral blood are discussed.

\section{Cells in Development of In Vitro Bone Models}

Advancement in development of in vitro bone models requires the selection of suitable cell models which can behave similarly to the ones in vivo. Cells that have been used in bonerelated studies might be originated from one of the following: immortalized cell lines, primary cells which are isolated directly from the tissue, induced pluripotent stem cells (iPSCs), and progenitor cells.

Immortalized cell lines such as MC3T3-E1, MLO-A5, and MG-63 have been used extensively in bone tissue engineering due to their ease of access, high expansion capacity, and reproducibility of outcomes [3]. However, these cell models do not always behave similarly to primary bone cells [26]. For instance, in murine calvarial cell line MC3T3-E1, the gene expression of specific transcripts coding for extracellular matrix proteins such as osteopontin may differ compared with primary osteoblastic cells $[27,28]$. Besides, as immortalized cell lines are not patient-specific, it is clear that they cannot be considered as suitable candidates for personalized human in vitro bone models.

iPSCs, which are generated by transferring a mixture of nuclear transcriptional factors including Oct4, Sox2, Klf4, and c-Myc to human primary cells, exhibit high similarity to human embryonic stem cells [29]. Due to their robust proliferation capacity, differentiation potential into many cell types, and the ability to generate patient-specific stem cells, iPSCs gained high interest in disease modeling, drug screening, and transplantation therapies [29]. Several studies have shown the ability of iPSCs to differentiate into osteoblasts and osteoclasts, suggesting that iPSCs could be considered as a cell model for the generation of in vitro bone models [30-33]. However, approaches to generate iPSCs might be complex, expensive, and time-consuming with low reprogramming efficiency and possible alternations of gene expression profiles and pathways, which make iPSCs less appropriate for development human in vitro bone models, at least for the moment.

Primary osteoblasts and osteocytes can both be directly isolated from bone tissue and provide an alternative to cell lines for bone-related studies. Several protocols and methods are available for the isolation of human osteoblasts including enzymatic digestion and spontaneous outgrowth cultures from bone biopsies [34, 35]. Isolation of primary osteocytes is more challenging due to their location within the mineralized bone matrix which requires multiple digestion and decalcification steps [36]. As an alternative, human osteocytes can be obtained in culture through differentiation of isolated osteoblasts under osteogenic stimulation [37, 38•]. For primary osteoclasts, it has been reported in early studies that they can be isolated from human bone tissue [39, 40]. However, isolation of primary osteoclasts from bone tissue requires multiple steps which might affect the number of extracted cells and their survival rate [41].

Primary cells have greatly enhanced the knowledge of bone biology; for instance, a recent study has shown development of an in vitro model to investigate the interaction of primary human osteoblasts and osteocytes [38•]. But due to their need for a bone biopsy, slow proliferation rate, short life-span, decreased doubling time after two or three passages, long isolation procedures, limited accessibility, restricted pool of potential donors (they are usually acquired during orthopedic surgery) [34, 42], their use for developing personalized human in vitro models is restricted.

The use of progenitor cells of the bone-specific cell types could be more promising to develop human in vitro bone models. MSCs are osteoblast/osteocyte progenitor cells which were primarily extracted from bone marrow and later from other tissues such as adipose tissue, muscle, peripheral blood, dental pulp as adult tissue sources and umbilical cord, umbilical cord blood, placenta, amniotic fluid as fetal and perinatal tissue sources [43-45]. MSCs can differentiate into various lineages such as adipogenic, chondrogenic, and osteogenic 
lineage under appropriate stimuli [46-48]. In addition to their multi-potency, their availability and relative ease of isolation and expansion have made them popular for use in many in vitro models. Bone marrow-derived MSCs have shown significant roles in bone regeneration and fracture repair in vivo; furthermore, in vitro studies demonstrated a high osteogenic differentiation capacity under biochemical and/or mechanical stimuli [49-53]. In bone tissue engineering, bone marrow has so far probably gained the greatest attention as a source of MSCs, but due to the invasive and painful procedure of bone marrow aspirate collection which can also cause donor site morbidity, other adult and fetal tissue sources have been studied as the source of MSCs [54]. For instance, several studies have indicated the osteogenic differentiation and bone formation potential of adipose-derived MSCs, which can be isolated from the tissue obtained during liposuction, lipoplasty, or lipectomy procedures with less discomfort and complications compared with bone marrow aspirate collection $[55,56]$. Further, MSCs derived from umbilical cord blood and peripheral blood with less invasive cell collection methods have also shown their potential for bone defect repair [57-59].

Hematopoietic stem cells (HSCs) are multi-potent and selfrenewing cells that can give rise to immune and blood cells $[60,61]$. HSCs are primarily located in the bone marrow and can be mobilized into the bloodstream which makes bone marrow and peripheral blood the common tissue sources for HSC extraction [62, 63••, 64]. Moreover, it has been shown that these cells can also be isolated from umbilical cord blood $[65,66]$. HSCs differentiate into the monocyte/macrophage lineage and further into osteoclasts under stimulation with receptor activator of nuclear factor kappa-B ligand (RANKL) and monocyte-colony-stimulating factors (MCSF), both of which are secreted in vivo by osteoblasts and osteocytes $[67,68]$.

Taken together, the most promising cell models for generation of personalized human in vitro bone models are progenitor cells. To develop these models, the patient's own progenitor cells should ideally be extracted from one source which makes the procedure more convenient for the patient, as well as results in less demanding clinical procedure. Among all adult tissue sources, due to the possibility to extract both MSCs and HSCs from bone marrow and peripheral blood, they can be considered being the most suitable sources for the isolation of osteoblast/osteocyte and osteoclast progenitor cells (Fig. 2).

\section{Bone Marrow-Derived MSCs vs. Peripheral Blood-Derived MSCs}

The frequency of MSCs derived from bone marrow and peripheral blood is very low, representing approximately $0.001-$ $0.01 \%$ and $0.000001 \%$ of isolated mononuclear cells, respectively $[69,70]$. The number of isolated MSCs can be changed depending on the gender, donor age, health condition, and in case of bone marrow-derived MSCs, skeletal site of isolation such as anterior or posterior iliac crest, vertebral body or femoral head [71-73]. It has been shown that the frequency of circulating MSCs in peripheral blood can be enhanced in response to pathological conditions such as bone fracture, osteoporosis, breast cancer, and bone sarcomas; for instance, a 9fold increase in the number of MSCs has been reported in the bloodstream of patients with osteosarcoma compared with control subjects [74-78]. This could be as a result of released cytokines and chemical signals to recruit MSCs and mobilize them into the bloodstream. Several methods have been used to mimic these signals to increase the number of MSCs in blood circulation such as administration of granulocyte-colonystimulating factor (G-CSF) and activation of the sympathetic nervous system by electro-acupuncture [79-82]. These methods could result in elevated number of isolated peripheral blood-derived MSCs which might be an advantage to develop patient-specific in vitro bone models; however, due to the possible side effects of stimulating the migration of cells from bone marrow to peripheral blood, it might not be ethical for the donors and also not applicable for patients with specific diseases [83]. To isolate MSCs from bone marrow and

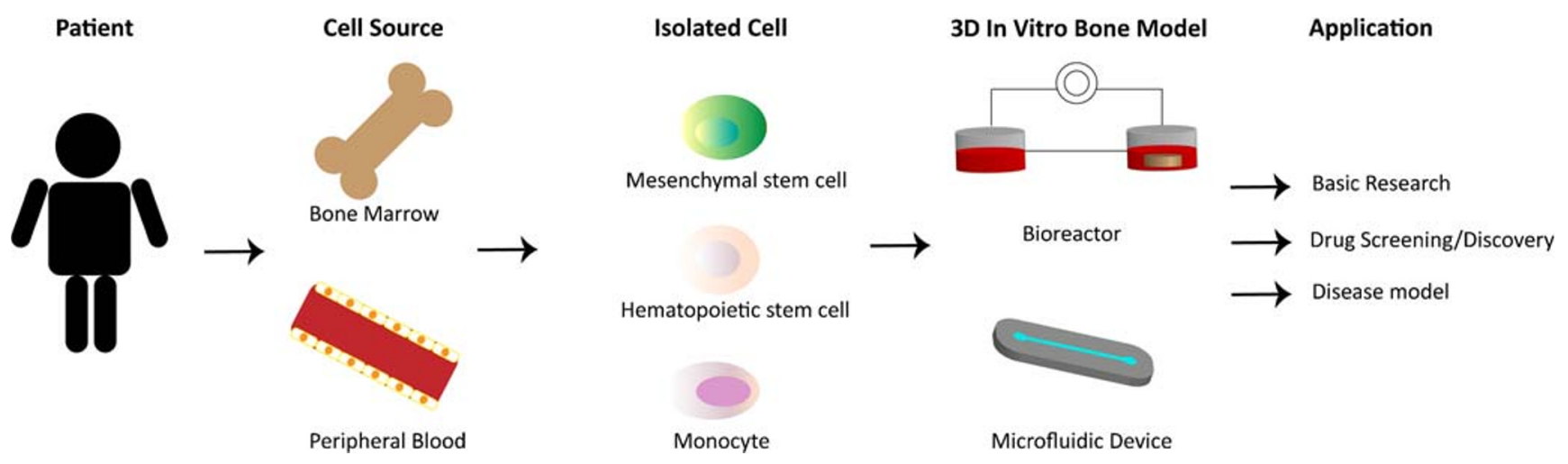

Fig. 2 Cell sources for personalized in vitro bone models 
peripheral blood, several protocols have been used such as direct plating based on the adherence property of MSCs to the plastic surface $[45,70]$, density gradient centrifugation, or hemolysis to separate mononuclear cells and remove erythrocytes prior to seeding cells on a plastic surface $[63,84-88$, 89•, 90, 91], using fibrin microbeads and fluorescenceactivated cell sorting (FACS) to increase the purity of extracted MSCs $[79,92]$. Due to the low frequency of isolated MSCs, their applicability relies on their high in vitro proliferation capacity.

The proliferation capacity of MSCs can be evaluated by calculating population doubling time [93]. Various studies on MSCs derived from bone marrow and peripheral blood have shown different doubling times for MSCs; for instance, 80 and $27 \mathrm{~h}$ of doubling times have been reported for bone marrow-derived MSCs and peripheral blood-derived MSCs, respectively [44]. These differences could also be as a result of donor-to-donor variability, factors such as age and health condition of the donor, passage number of cells in vitro and the use of different protocols for cell isolation and culture [76, 87, 94-101]. For instance, isolation of peripheral blood-derived MSCs based on positive expression of CD133 led to obtain MSCs with high proliferative potential in comparison with the peripheral blood-derived MSCs based on their adherence capability to plastic surface [101]. This could be due to the heterogeneous population of cells in the plastic adherence method that might interfere with proliferation capacity. While an investigation on bone marrow- and peripheral blood-derived MSCs obtained from same patients with the same isolation method and culture condition has reported no significant differences in their characteristics such as population doubling time [76], in another study, the quantity of obtained MSCs from bone marrow after two passages was 2 times higher than MSCs from peripheral blood [89•]. These differences not only could be a result of donor variation, but also of the culture condition and most importantly the medium composition. Even though these observations could suggest that the use of peripheral blood-derived MSCs in tissue engineering applications might be equally valuable as bone marrow-derived MSCs, the chosen culture conditions need to be evaluated carefully.

The in vitro osteogenic differentiation of MSCs makes them highly interesting for the development of in vitro bone models $[63,76,89 \cdot, 102-106]$. The general trend shows a beneficial osteogenic differentiation potential for bone marrow-derived MSCs based on significantly increased expression of osteoblastic specific genes, such as alkaline phosphatase (ALP) and calcium deposition compared with other tissue sources [106, 107]. On the other hand, studies on MSCs extracted from bone marrow and peripheral blood of the same patients have shown no significant differences in quantitative measurements of ALP expression and calcium content; moreover, MSCs from both sources have demonstrated positive staining for calcium deposits [76, 89]. Besides the differentiation potential of MSCs towards the osteogenic lineage, their ability to promote bone formation after in vivo implantation has been shown in various studies. The majority of these studies has been conducted using bone marrow-derived MSCs in human and animal models [108-112]. In a small number of studies, also peripheral blood-derived MSCs have been used and shown to enhance bone regeneration in critical-sized bone defects in animal models $[59,113,114]$. Taken together, peripheral blood-derived MSCs seem to exhibit similar characteristics as bone marrow-derived MSCs and can be used to develop patient-specific in vitro bone models.

The main challenge in developing in vitro bone models to represent bone remodeling is the formation of osteocytes embedded in the mineralized matrix. In vitro, human osteocytes have been obtained through the differentiation of primary osteoblasts, but so far, full differentiation of MSCs towards functional osteocytes has not been reported (Table 1). Further investigations will be needed to induce the formation of osteocytes that are embedded in their own matrix in vitro. This might be acquired for example through exposing cells to mechanical stimuli which are known to be involved in bone homeostasis and bone remodeling [3, 123].

\section{Bone Marrow-Derived HSCs Vs Peripheral Blood-Derived HSCs}

HSCs represent a rare population of cells in bone marrow and peripheral blood, representing less than $0.01 \%$ and less than $0.000001 \%$ of total nucleated cells, respectively [124-127]. However, the population of cells could be influenced by the age and health condition of patients and the method of cell isolation [128-131]. HSCs are primarily located in the bone marrow, but, just like MSCs, they display dynamic behavior by moving out of the bone marrow and entering into the general circulation $[68,132]$. The mobilization process could be enhanced by administration of various factors and depending on the type of used pharmacological agent such as G-CSF and CXCR4 receptor antagonist AMD3100, the frequency of HSCs in peripheral blood could be elevated up to 100 times [68, 132-135]. However, the possible side effects of exposing donors to these pharmacological agents might not be ethical for the donors [83]. Luckily, monocytes that are derived from HSCs and comprise 10-20\% of peripheral blood mononuclear cells can be directly isolated from peripheral blood and have been used as osteoclast precursor cells in in vitro studies [136-142]. To isolate HSCs from bone marrow and peripheral blood, several protocols have been developed including direct plating of bone marrow aspirates and blood samples on plastic surface and collecting the non-adherent cells as it has been shown that HSCs are less likely to attach to the plastic substrate compared with MSCs. The molecular and biochemical 
Table 1 Current approaches to differentiate osteocytes in vitro

\begin{tabular}{|c|c|c|c|c|}
\hline Cell & Osteoblast source & Culture substrate & Outcome & Reference \\
\hline Human primary osteoblasts & Purchased from LONZA & $\begin{array}{l}\text { Biphasic calcium phosphate } \\
\text { particles }\end{array}$ & $\begin{array}{l}\text { Expression of CX43, DMP1, E11, } \\
\text { MEPE, SOST, PHEX } \\
\text { Embedded osteocyte-like cells in } \\
\text { collagenous matrix }\end{array}$ & [115] \\
\hline Human primary osteoblasts & $\begin{array}{l}\text { Femoral trabecular bone } \\
\text { tissue from the knee region }\end{array}$ & Mineralized collagen matrix & $\begin{array}{l}\text { Expression of DMP } 1 \text { and FGF } 23 \\
\text { Formation of lacunae around the cell }\end{array}$ & [116] \\
\hline \multirow[t]{2}{*}{$\begin{array}{l}\text { Human primary pre-osteoblasts } \\
\text { and mature osteoblasts }\end{array}$} & $\begin{array}{l}\text { Spongious bone fragment of } \\
\text { human femoral head }\end{array}$ & Collagen gel & $\begin{array}{l}\text { Expression of E11, osteocalcin, } \\
\text { PHEX, MEPE, RANKL } \\
\text { Acquire stellar shape of osteocyte }\end{array}$ & {$[38 \bullet]$} \\
\hline & & Mineralized collagen gel & $\begin{array}{l}\text { Expression of ALP, PDPN, PHEX } \\
\text { Acquire stellar shape of osteocyte }\end{array}$ & {$[37]$} \\
\hline Human primary osteoblasts & Intertrochanteric bone & $2 \mathrm{D}$ on tissue culture plastic & $\begin{array}{l}\text { Expression of E11, DMP1, SOST, } \\
\text { OOCN, BSP1, PHEX }\end{array}$ & {$[117]$} \\
\hline Human primary osteoblasts & Knee cortical & $\begin{array}{l}\text { 3D microfluidic perfusion } \\
\text { device }\end{array}$ & $\begin{array}{l}\text { Expression of SOST and FGF23 } \\
\text { Form 3D cellular network } \\
\text { Inhibit cell proliferation }\end{array}$ & {$[118]$} \\
\hline Mouse primary osteoblasts & Long bone & $\begin{array}{l}\text { 3D microfluidic perfusion } \\
\text { device }\end{array}$ & $\begin{array}{l}\text { Expression SOST, FGF23 } \\
\text { Form 3D cellular network } \\
\text { Inhibit cell proliferation }\end{array}$ & [119] \\
\hline Mouse primary osteoblasts & Calvarial tissue & $\begin{array}{l}\text { 2D culture on } \\
\text { poly-L-lysine-coated 2-well } \\
\text { chamber slide }\end{array}$ & $\begin{array}{l}\text { Expression of ALP, DMP1, sclerostin } \\
\text { Formation of mineralized nodules } \\
\text { Acquire stellar shape of osteocyte }\end{array}$ & {$[120]$} \\
\hline Rat primary periosteal cells & Femur bone & $\begin{array}{l}\text { Fibrin hydrogel with calcium } \\
\text { phosphate ceramic anchors }\end{array}$ & $\begin{array}{l}\text { Deposition of ordered matrix } \\
\text { containing collagen and } \\
\text { hydroxyapatite } \\
\text { Expression of sclerostin and PDPN } \\
\text { Embedded cell with osteocyte } \\
\text { morphology in the mineralized } \\
\text { matrix }\end{array}$ & {$[121]$} \\
\hline Mouse mesenchymal stem cell & Bone marrow & $\begin{array}{l}2 \mathrm{D} \text { culture on tissue culture } \\
\text { plastic }\end{array}$ & $\begin{array}{l}\text { Formation of mineralized nodules } \\
\text { Expression of E11, DMP1, PHEX, } \\
\text { SOST, FGF23, RANKL, OPG. } \\
\text { Acquire stellar shape of osteocyte }\end{array}$ & {$[122]$} \\
\hline
\end{tabular}

analyses on the non-adherent cells of bone marrow and peripheral blood mononuclear cells revealed that they are positive for HSC markers such as SLAM F1 [63••]. Culturing nonadherent cells in osteoclastogenesis promoting medium resulted in the differentiation of functional osteoclasts which was associated with expression of the tartrate-resistant acid phosphatase (TRAP) gene and an increased TRAP enzyme activity $[62,63,143 \bullet \bullet, 144]$. Another method is culturing mononuclear cells separated via density gradient centrifugation under osteoclastogenic culture condition which led to the generation of osteoclasts in culture [145, 146]. Moreover, HSCs and monocytes can be isolated and purified based on the expression of their own specific surface marker such as CD34 and CD14 using techniques including an automated magnetic purification system and FACS [124, 125, 136-138, 147-150].

Unlike MSCs which exhibit a high proliferation capacity and can be expanded in vitro to obtain a high number of cells for in vitro studies, the proliferation of HSCs and monocytes remains challenging. For the generation of in vitro bone models and osteoclast-related studies, freshly isolated osteoclast progenitor cells have been used in most studies [137, 151-153]. The time-consuming procedure of cell isolation might cause difficulties in obtaining a high enough number of cells; as a result, large volume of bone marrow aspirates or peripheral blood would be required. Attempts to increase the number of osteoclast precursor cells in vitro resulted in the development and use of several components and factors in culture [126]. It has been shown that combinations of growth factors and cytokines such as interleukin 6 (IL-6), interleukin 3 (IL-3), thrombopoietin (TPO), and stem cell factor (SCF) with additional molecules such as Prostaglandin E2 (PGE2), Stemregenin 1 (SR1), and UM171 could support the proliferation of HSCs in vitro [126, 154-156]. Monocytes have also showed an increased proliferation potential in vitro in response to macrophage-colony-stimulating factor (M-CSF), $1 \alpha, 25$-dihydroxyvitamin D3, and lymphokines [157-161]. However, the influence of these components on the subsequent osteoclastogenesis potential needs further investigation. 
Cryopreservation of osteoclast progenitor cells seems feasible as it has not affected monocyte viability and function in response to various factors [162-165]. However, further exploration is required on the osteoclast differentiation ability of cryopreserved osteoclast progenitor cells.

Osteoclast differentiation of both HSCs and monocytes derived from bone marrow and peripheral blood has been shown in several in vitro studies [67, 152, 153]. Variations in donor age, health condition, and osteoclastogenesis protocols have resulted in mixed outcomes regarding osteoclast differentiation capacity [143, 166, 167]. For instance, a mixture of growth factors such as RANKL, M-CSF, transforming growth factor beta (TGF- $\beta$ ), and dexamethasone has led to the generation of multinuclear cells with higher number of nuclei and an increased expression of osteoclast-specific genes such as tartrate-resistant acid phosphatase (TRACP) 5a and 5b in peripheral blood-derived monocytes compared with bone marrow-derived monocytes (Fig. 3) [143••]. However, no significant differences were reported in bone resorption activity between the used cell types and growth factor combinations $[143 \bullet \bullet$. This study highlighted the importance of carefully considering the combination of chosen growth factors for the osteoclastogenesis of osteoclast precursor cells.

\section{Conclusion}

In vitro bone models provide a platform to study bone physiology including bone remodeling, bone-related diseases, and potential treatments. These models require all three types of cells in bone, namely osteoblasts, osteocytes, and osteoclasts, ideally from individuals to account for donor-specific differences and disease-related cell reactions. To achieve that, it is required to collect progenitor cells from one patient and ideally from one cell source for patient convenience. MSCs and HSCs are progenitor cells of osteoblasts/osteocytes and osteoclasts, respectively, and can be extracted from both bone marrow and peripheral blood as reviewed here. Limited studies directly comparing bone marrow-derived and peripheral blood-derived MSCs and HSCs have shown no significant differences between osteogenesis and osteoclastogenesis of the progenitor cells from both sources. However, many

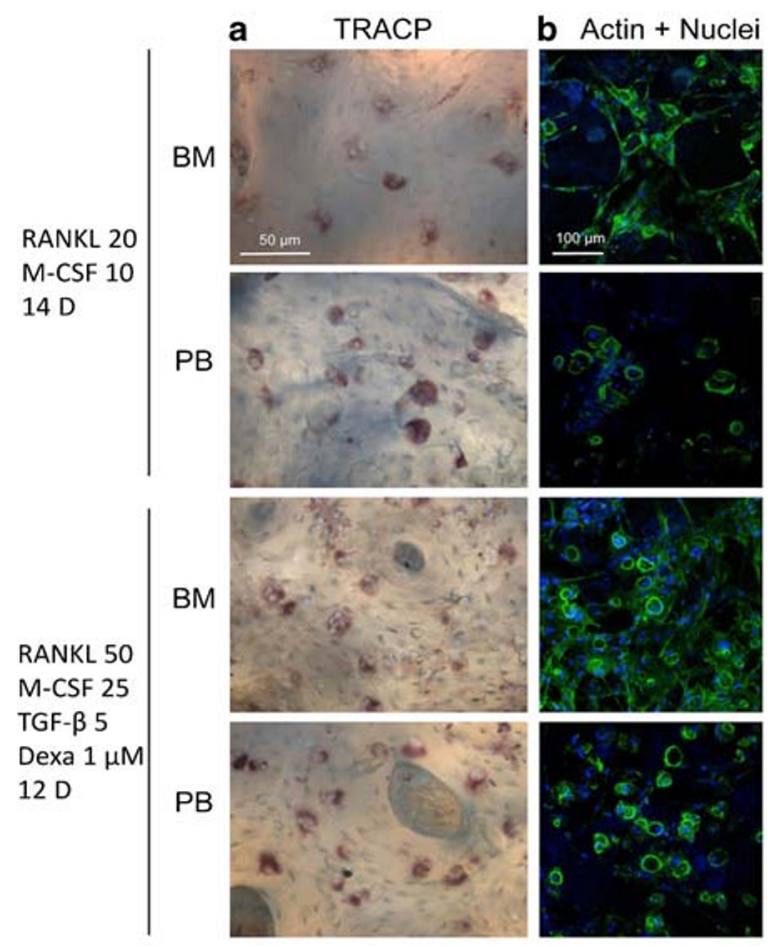

Fig. 3 Osteoclast differentiated from bone marrow and peripheral blood cultures under different combination of growth factors. The multinuclear TRACP-positive cells are shown in a and the actin rings are illustrated in b. Higher number of multinuclear cells in bone marrow-derived cultures were obtained in the presence of RANKL and M-CSF (c). The number of nuclei in multinuclear cell was similar in bone marrow and peripheral blood-derived osteoclasts when only RANKL and M-CSF were used,

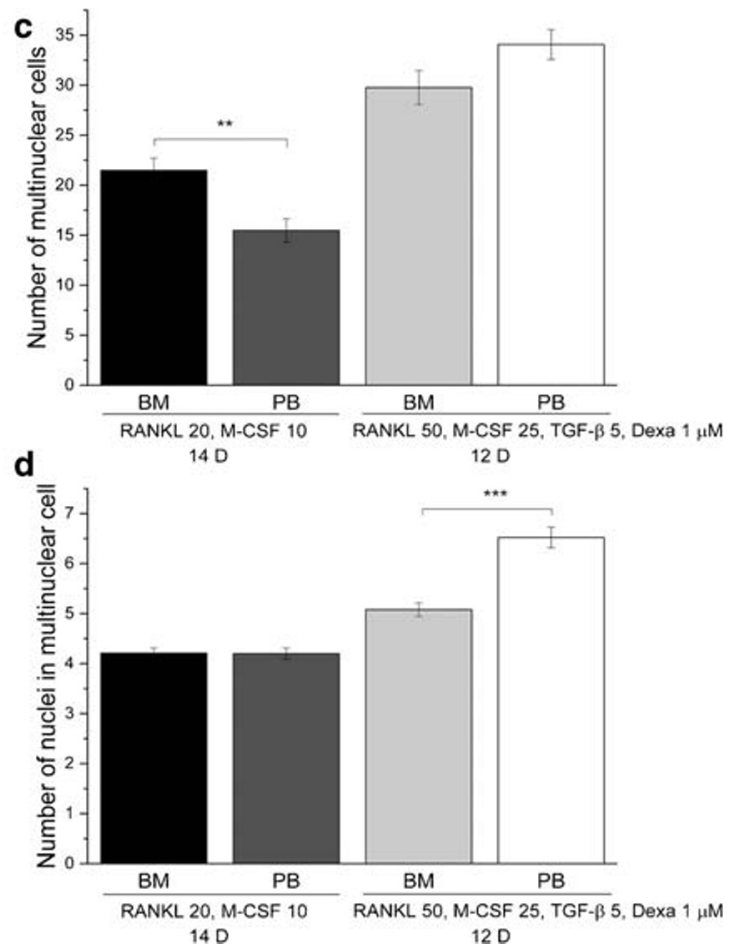

but in the presence of dexamethasone, the peripheral blood-derived osteoclasts contained significantly more nuclei (d). 12D and 14D: 12 and 14 days of culture, respectively [143]. Reprinted from Heliyon, Vol 4, Elina Kylmäoja et al. Peripheral blood monocytes show increased osteoclast differentiation potential compared with bone marrow monocytes, Copyright (2018) with permission from Elsevier 
Table 2 Comparison between MSCs and HSCs/monocytes derived from bone marrow and peripheral blood for in vitro studies

\begin{tabular}{|c|c|c|c|c|c|}
\hline Cell & Source & $\begin{array}{l}\text { Collection } \\
\text { invasiveness }\end{array}$ & $\begin{array}{l}\text { Frequency } \\
\text { of cells }\end{array}$ & $\begin{array}{l}\text { Proliferation } \\
\text { capacity }\end{array}$ & $\begin{array}{l}\text { Differentiation } \\
\text { potential }^{\mathrm{a}}\end{array}$ \\
\hline \multirow[t]{2}{*}{$\begin{array}{l}\text { Mesenchymal stem cells } \\
\text { (MSCs) }\end{array}$} & $\begin{array}{l}\text { Bone } \\
\text { marrow }\end{array}$ & +++ & ++ & +++ & +++ \\
\hline & $\begin{array}{l}\text { Peripheral } \\
\text { blood }\end{array}$ & + & + & +++ & +++ \\
\hline \multirow[t]{2}{*}{$\begin{array}{l}\text { Hematopoietic stem cells } \\
\text { (HSCs)/monocytes }\end{array}$} & $\begin{array}{l}\text { Bone } \\
\text { marrow }\end{array}$ & +++ & + & + & +++ \\
\hline & $\begin{array}{l}\text { Peripheral } \\
\text { blood }\end{array}$ & + & +++ & + & +++ \\
\hline
\end{tabular}

${ }^{\mathrm{a}}$ The differentiation potential of MSCs and HSCs/monocytes strongly depends on the culture condition parameters such as medium composition have been reported to affect cell proliferation and their differentiation potential which could make the peripheral blood-derived stem cells superior to the ones from bone marrow. Thus, as both sources have their advantages and disadvantages (Table 2), yet, peripheral blood could be considered as a suitable source for both osteoblast/osteocyte and osteoclast progenitor cells, being less invasive for the patient. In this case, more investigations are needed focusing on extraction and differentiation of both cell types from the same sample of peripheral blood.

Code Availability Not applicable.

Authors' Contributions S.A. and S.H. conceptualized the review, S.A. collected and sorted the literature and wrote the draft. S.A., S.H., and K.I. edited and reviewed the manuscript.

Funding We gratefully acknowledge the financial support by the Ministry of Education, Culture and Science, Gravitation Program number 024.003.013 (Materials Driven Regeneration), and project number TTW 016.Vidi.188.021 (MiniBones) funded by the Dutch Organization for Scientific Research (NWO)

Data Availability Not applicable.

\section{Compliance with Ethical Standards}

Conflict of Interest The authors declare no conflict of interest.

Open Access This article is licensed under a Creative Commons Attribution 4.0 International License, which permits use, sharing, adaptation, distribution and reproduction in any medium or format, as long as you give appropriate credit to the original author(s) and the source, provide a link to the Creative Commons licence, and indicate if changes were made. The images or other third party material in this article are included in the article's Creative Commons licence, unless indicated otherwise in a credit line to the material. If material is not included in the article's Creative Commons licence and your intended use is not permitted by statutory regulation or exceeds the permitted use, you will need to obtain permission directly from the copyright holder. To view a copy of this licence, visit http://creativecommons.org/licenses/by/4.0/.

\section{References}

Papers of particular interest, published recently, have been highlighted as:

- Of importance

- Of major importance

1. Clarke B. Normal bone anatomy and physiology. Clin J Am Soc Nephrol. 2008;3(Suppl 3):131-9.

2. Hadjidakis DJ, Androulakis II. Bone remodeling. Ann N Y Acad Sci. 2006;1092:385-96.

3. Perrault CM. In vitro bone cell models : impact of fluid shear stress on bone formation. Frintiers Bioeng. Biotech. 2016;4(November).

4. Wang J, et al. Mechanical stimulation orchestrates the osteogenic differentiation of human bone marrow stromal cells by regulating HDAC1. Cell Death Dis. 2016;7:e2221.

5. Katarivas Levy G, Birch MA, Brooks RA, Neelakantan S, Markaki AE. Stimulation of human osteoblast differentiation in magneto-mechanically actuated ferromagnetic fiber networks. J Clin Med. 2019;8(10).

6. Marks SJ, Popoff S. Bone cell biology: the regulation of development, structure, and function in the skeleton. Am J Anat. 1988;183(1):1-44.

7. Gorski JP. Biomineralization of bone: a fresh view of the roles of non-collagenous proteins. Front Biosci. 2011;16(7):2598-621.

8. Boonrungsiman S, Gentleman E, Carzaniga R, Evans ND, McComb DW, Porter AE, et al. The role of intracellular calcium phosphate in osteoblast-mediated bone apatite formation. Proc Natl Acad Sci. 2012;109(35):14170-5.

9. Manolagas SC. Birth and death of bone cells: basic regulatory mechanisms and implications for the pathogenesis and treatment of osteoporosis. Endocr Rev. Apr. 2000;21(2):115-37.

10. Franz-Odendaal TA, Hall BK, Witten PE. Buried alive: how osteoblasts become osteocytes. Dev Dyn. 2006;235(1):176-90.

11. Bonewald LF. The amazing osteocyte. J Bone Miner Res. 2011;26(2):229-38.

12. Hao Z, Ma Y, Wu J, Li X, Chen H, Shen J, et al. Osteocytes regulate osteoblast differentiation and osteoclast activity through interleukin-6 under mechanical loading. RSC Adv. 2017;7(79): 50200-9.

13. Boyle WJ, Simonet WS, Lacey DL. Osteoclast differentiation and activation. Nature. 2003;423:337-42. 
14. Crockett JC, Rogers MJ, Coxon FP, Hocking LJ, Helfrich MH. Bone remodelling at a glance. J Cell Sci. 2011;124(7):991-8.

15. Boyle WJ, Simonet WS, Lacey DL. Osteoclast differentiation and activation. Nature. 2003;423(6937):337-42.

16. Hinton RJ, Jing Y, Jing J, Feng JQ. Roles of chondrocytes in endochondral bone formation and fracture repair. J Dent Res. 2017;96(1):23-30.

17. Sivaraj KK, Adams RH. Blood vessel formation and function in bone. Development. Aug. 2016;143(15):2706-15.

18. Owen R, Reilly GC. In vitro models of bone remodelling and associated disorders. Front Bioeng Biotechnol. 2018;6:134.

19. L. G. Raisz, Science in medicine pathogenesis of osteoporosis: concepts , conflicts , and prospects, J Clin Invest, vol. 115, no. 12, pp. 3318-3325., 2005.

20. Feng X, McDonald JM. Disorders of bone remodeling. Annu Rev Pathol. 2011;6:121-45.

21. Seok J, et al. Genomic responses in mouse models poorly mimic human inflammatory diseases. Proc Natl Acad Sci. 2013;110(9): 3507 LP - 3512.

22. Knight A. Systematic reviews of animal experiments demonstrate poor human clinical and toxicological utility. Altern Lab Anim. Dec. 2007;35(6):641-59.

23. Scheinpflug J, et al. Journey into bone models: a review. Genes (Basel). 2018;9(5).

24. Benam KH, Dauth S, Hassell B, Herland A, Jain A, Jang KJ, et al. Engineered in vitro disease models. Annu Rev Pathol Mech Dis. 2015;10(1):195-262.

25. Fong ELS, Toh TB, Yu H, Chow EKH. 3D culture as a clinically relevant model for personalized medicine. SLAS Technol. 2017;22(3):245-53.

26. Czekanska EM, Stoddart MJ, Ralphs JR, Richards RG, Hayes JS. A phenotypic comparison of osteoblast cell lines versus human primary osteoblasts for biomaterials testing. J Biomed Mater Res A. Aug. 2014;102(8):2636-43.

27. Hwang PW, Horton JA. Variable osteogenic performance of MC3T3-E1 subclones impacts their utility as models of osteoblast biology. Sci Rep. 2019;9(1):8299.

28. Bouet G, Marchat D, Cruel M, Malaval L, Vico L. In vitro threedimensional bone tissue models: from cells to controlled and dynamic environment. Tissue Eng - Part B Rev. 2015;21(1):133-56.

29. Yu J, Thomson JA. Chapter 30 - induced pluripotent stem cells. In: Lanza R, Langer R, J. B. T.-P. of T. E. (Fourth E. Vacanti), editors. Principles of tissue engineering. 4th ed. Boston: Academic Press; 2014. p. 581-94.

30. Csobonyeiova M, Polak S, Zamborsky R, Danisovic L. iPS cell technologies and their prospect for bone regeneration and disease modeling: a mini review. J Adv Res. 2017;8(4):321-7.

31. Jeon OH, Panicker LM, Lu Q, Chae JJ, Feldman RA, Elisseeff JH. Human iPSC-derived osteoblasts and osteoclasts together promote bone regeneration in 3D biomaterials. Sci Rep. 2016;6(1):26761.

32. Bastami F, Nazeman P, Moslemi H, Rezai Rad M, Sharifi K, Khojasteh A. Induced pluripotent stem cells as a new getaway for bone tissue engineering: a systematic review. Cell Prolif. $2017 ; 50(2)$

33. Grigoriadis AE, Kennedy M, Bozec A, Brunton F, Stenbeck G, Park IH, et al. Directed differentiation of hematopoietic precursors and functional osteoclasts from human ES and iPS cells. Blood. 2010;115(14):2769-76.

34. Czekanska EM, Stoddart MJ, Richards RG, Hayes JS. In search of an osteoblast cell model for in vitro research. Eur. Cells Mater. 2012;24:1-17.
35. Gartland A, Rumney RMH, Dillon JP, Gallagher JA. Isolation and culture of human osteoblasts. In: Mitry RR, Hughes RD, editors. Human cell culture protocols. Totowa, NJ: Humana Press; 2012. p. 337-55.

36. Prideaux M, Schutz C, Wijenayaka AR, Findlay DM, Campbell DG, Solomon LB, et al. Isolation of osteocytes from human trabecular bone. Bone. 2016;88:64-72.

37. Bernhardt A, Weiser E, Wolf S, Vater C, Gelinsky M. Primary human osteocyte networks in pure and modified collagen gels. Tissue Eng - Part A. 2019;25(19-20):1347-55.

38. Skottke J, Gelinsky M, Bernhardt A. In vitro co-culture model of primary human osteoblasts and osteocytes in collagen gels. Int $\mathrm{J}$ Mol Sci. 2019;20(8) This study investigate the interaction between osteoblasts and osteocytes in an in vitro model comprosing solely primary human cells.

39. Lambrecht JT, Marks SCJ. Human osteoclast-like cells in primary culture. Clin Anat. 1996;9(1):41-5.

40. Benito GE, Sánchez ML, del Pino-Montes J, Calvo JJ, Menéndez $\mathrm{P}$, García-Marcos MA, et al. A new cytometric method for the immunophenotypic characterization of bone-derived human osteoclasts. Cytometry. Oct. 2002;50(5):261-6.

41. Rucci N, Zallone A, Teti A. Isolation and generation of osteoclasts. In: Idris AI, editor. Bone research protocols. New York, NY: Springer New York; 2019. p. 3-19.

42. Liu B, Lu Y, Wang Y, Ge L, Zhai N, Han J. A protocol for isolation and identification and comparative characterization of primary osteoblasts from mouse and rat calvaria. Cell Tissue Bank. 2019;20(2):173-82.

43. Robey PG. Cell sources for bone regeneration: the good, the bad, and the ugly (but promising). Tissue Eng Part B Rev. Dec. 2011;17(6):423-30.

44. Brown C, McKee C, Bakshi S, Walker K, Hakman E, Halassy S, et al. Mesenchymal stem cells: cell therapy and regeneration potential. J Tissue Eng Regen Med. 2019;13(9):1738-55.

45. Zwaifler NJ, et al. Mesenchymal precursor cells in the blood of normal individuals. Arthritis Res. 2000;2(6):477-88.

46. Janderova L, McNeil M, Murrell AN, Mynatt RL, Smith SR. Human mesenchymal stem cells as an in vitro model for human adipogenesis. Obes Res. 2003;11(1):65-74.

47. Musumeci G, Mobasheri A, Trovato FM, Szychlinska MA, Graziano ACE, Lo Furno D, et al. Biosynthesis of collagen I, II, RUNX2 and lubricin at different time points of chondrogenic differentiation in a 3D in vitro model of human mesenchymal stem cells derived from adipose tissue. Acta Histochem. 2014;116(8):1407-17.

48. Persson $\mathrm{M}$, et al. Osteogenic differentiation of human mesenchymal stem cells in a 3D woven scaffold. Sci Rep. 2018;8(1):10457.

49. Niedzwiedzki T. Effect of bone marrow on healing of fractures, delayed unions and pseudoarthroses of long bones. Chir Narzadow Ruchu Ortop Pol. 1993;58(3):194-204.

50. Taguchi K, Ogawa R, Migita M, Hanawa H, Ito H, Orimo H. The role of bone marrow-derived cells in bone fracture repair in a green fluorescent protein chimeric mouse model. Biochem Biophys Res Commun. May 2005;331(1):31-6.

51. Mauney JR, Sjostorm S, Blumberg J, Horan R, O’Leary JP, Vunjak-Novakovic G, et al. Mechanical stimulation promotes osteogenic differentiation of human bone marrow stromal cells on 3D partially demineralized bone scaffolds in vitro. Calcif Tissue Int. 2004;74(5):458-68.

52. Sumanasinghe RD, Bernacki SH, Loboa EG. Osteogenic differentiation of human mesenchymal stem cells in collagen matrices: 
effect of uniaxial cyclic tensile strain on bone morphogenetic protein (BMP-2) mRNA expression. Tissue Eng. 2006;12(12):345965.

53. Yourek G, McCormick SM, Mao JJ, Reilly GC. Shear stress induces osteogenic differentiation of human mesenchymal stem cells. Regen Med. Sep. 2010;5(5):713-24.

54. Hass R, Kasper C, Böhm S, Jacobs R. Different populations and sources of human mesenchymal stem cells (MSC): a comparison of adult and neonatal tissue-derived MSC. Cell Commun Signal. 2011;9(1):12.

55. Dai R, Wang Z, Samanipour R, Koo K, Kim K. Adipose-derived stem cells for tissue engineering and regenerative medicine applications. Stem Cells Int. 2016;2016:6737345.

56. Probst FA, et al. Bone regeneration of minipig mandibular defect by adipose derived mesenchymal stem cells seeded tri-calcium phosphate- poly(D,L-lactide-co-glycolide) scaffolds. Sci Rep. 2020;10(1):2062.

57. Sane MS, Misra N, Mousa OM, Czop S, Tang H, Khoo LT, et al. Cytokines in umbilical cord blood-derived cellular product: a mechanistic insight into bone repair. Regen Med. Dec. 2018;13(8):88198.

58. Hong B, Lee S, Shin N, Ko Y, Kim DW, Lee J, et al. Bone regeneration with umbilical cord blood mesenchymal stem cells in femoral defects of ovariectomized rats. Osteoporos Sarcopenia. 2018;4(3):95-101.

59. Wu G, et al. Osteogenesis of peripheral blood mesenchymal stem cells in self assembling peptide nanofiber for healing critical size calvarial bony defect. Sci Rep. 2015;5(June):1-12.

60. Zhang P, Zhang C, Li J, Han J, Liu X, Yang H. The physical microenvironment of hematopoietic stem cells and its emerging roles in engineering applications. Stem Cell Res Ther. 2019;10(1): $1-13$.

61. Cora MC, Latimer K, Travlos GS. Chapter 25 - bone marrow: Elsevier Inc.; 2018

62. Maridas DE, Rendina-Ruedy E, Le PT, Rosen CJ. Isolation, culture, and differentiation of bone marrow stromal cells and osteoclast progenitors from mice. J Vis Exp. 2018;2018(131):1-7.

63.• Kadir RA, Ariffin SHZ, Wahab RMA, Kermani S, Senafi S. Characterization of mononucleated human peripheral blood cells. Sci World J. 2012;2012 This study demostrates the possibility of isolation both osteoblast/osteocyte and osteclast progentor cells from peripheral blood.

64. Guezguez B, Campbell CJV, Boyd AL, Karanu F, Casado FL, di Cresce $\mathrm{C}$, et al. Regional localization within the bone marrow influences the functional capacity of human HSCs. Cell Stem Cell. 2013;13(2):175-89.

65. Ishigaki T, et al. Human hematopoietic stem cells can survive in vitro for several months. Adv Hematol. 2009;2009:936761.

66. Hordyjewska A, Popiolek L, Horecka A. Characteristics of hematopoietic stem cells of umbilical cord blood. Cytotechnology. May 2015;67(3):387-96.

67. Kohli N, Ho S, Brown SJ, Sawadkar P, Sharma V, Snow M, et al. Bone remodelling in vitro: where are we headed?: -a review on the current understanding of physiological bone remodelling and inflammation and the strategies for testing biomaterials in vitro. Bone. 2018;110:38-46.

68. Bonig H, Papayannopoulou T. Mobilization of hematopoietic stem/progenitor cells: general principles and molecular mechanisms. Methods Mol Biol. 2012;904:1-14.

69. Pittenger MF, Mackay AM, Beck SC, Jaiswal RK, Douglas R, Mosca JD, et al. Multilineage potential of adult human mesenchymal stem cells. Science. Apr. 1999;284(5411):143-7.

70. Kuznetsov SA, Mankani MH, Gronthos S, Satomura K, Bianco P, Robey PG. Circulating skeletal stem cells. J Cell Biol. May 2001;153(5):1133-40.
71. Herrmann M, et al. Phenotypic characterization of bone marrow mononuclear cells and derived stromal cell populations from human iliac crest, vertebral body and femoral head. Int J Mol Sci. 2019;20(14).

72. Patterson TE, et al. The efficiency of bone marrow aspiration for the harvest of connective tissue progenitors from the human iliac crest. J Bone Jt Surg - Am Vol. 2017;99(19):1673-82.

73. Pierini M, di Bella C, Dozza B, Frisoni T, Martella E, Bellotti C, et al. The posterior iliac crest outperforms the anterior iliac crest when obtaining mesenchymal stem cells from bone marrow. J bone Jt surgury Am. 2013;95(12):1101-7.

74. Bian ZY, Li G, Gan YK, Hao YQ, Xu WT, Tang TT. Increased number of Mesenchymal stem cell-like cells in peripheral blood of patients with bone sarcomas. Arch Med Res. 2009;40(3):163-8.

75. Lan Y, Kodati S, Lee HS, Omoto M, Jin Y, Chauhan SK. Kinetics and function of mesenchymal stem cells in corneal injury. Investig Ophthalmol Vis Sci. 2012;53(7):3638-44.

76. Alm JJ, Koivu HMA, Heino TJ, Hentunen TA, Laitinen S, Aro HT. Circulating plastic adherent mesenchymal stem cells in aged hip fracture patients. J Orthop Res. 2010;28(12):1634-42.

77. Fernandez M, Simon V, Herrera G, Cao C, Del Favero H, Minguell JJ. Detection of stromal cells in peripheral blood progenitor cell collections from breast cancer patients. Bone Marrow Transplant. 1997;20(4):265-71.

78. Carbonare LD, Valenti MT, Zanatta M, Donatelli L, Lo Cascio V. Circulating mesenchymal stem cells with abnormal osteogenic differentiation in patients with osteoporosis. Arthritis Rheum. Nov. 2009;60(11):3356-65.

79. Kassis I, Zangi L, Rivkin R, Levdansky L, Samuel S, Marx G, et al. Isolation of mesenchymal stem cells from G-CSF-mobilized human peripheral blood using fibrin microbeads. Bone Marrow Transplant. 2006;37(10):967-76.

80. $\mathrm{Xu} \mathrm{L}, \mathrm{Li}$ G. Circulating mesenchymal stem cells and their clinical implications. J Orthop Transl. 2014;2(1):1-7.

81. Longhini ALF, et al. Peripheral blood-derived mesenchymal stem cells demonstrate immunomodulatory potential for therapeutic use in horses. PLoS One. 2019;14(3):1-15.

82. Salazar TE, et al. Electroacupuncture promotes central nervous system-dependent release of mesenchymal stem cells. Stem Cells. May 2017;35(5):1303-15.

83. Moalic-Allain V. Medical and ethical considerations on hematopoietic stem cells mobilization for healthy donors. Transfus Clin Biol. May 2018;25(2):136-43.

84. Secunda R, Vennila R, Mohanashankar AM, Rajasundari M, Jeswanth S, Surendran R. Isolation, expansion and characterisation of mesenchymal stem cells from human bone marrow, adipose tissue, umbilical cord blood and matrix: a comparative study. Cytotechnology. 2015;67(5):793-807.

85. Penfornis P, Pochampally R. Isolation and expansion of mesenchymal stem cells/multipotential stromal cells from human bone marrow. Methods Mol Biol. 2011;698:11-21.

86. Hua J, et al. Comparison of different methods for the isolation of mesenchymal stem cells from umbilical cord matrix: proliferation and multilineage differentiation as compared to mesenchymal stem cells from umbilical cord blood and bone marrow. Cell Biol Int. 2013.

87. Pösel C, Möller K, Fröhlich W, Schulz I, Boltze J, Wagner D-C. Density gradient centrifugation compromises bone marrow mononuclear cell yield. PLoS One. 2012;7(12):e50293.

88. Meuleman N, Tondreau T, Delforge A, Dejeneffe M, Massy M, Libertalis M, et al. Human marrow mesenchymal stem cell culture: serum-free medium allows better expansion than classical $\alpha$ MEM medium. Eur J Haematol. 2006;76(4):309-16.

89. Chong P-P, Selvaratnam L, Abbas AA, Kamarul T. Human peripheral blood derived mesenchymal stem cells demonstrate similar characteristics and chondrogenic differentiation potential to 
bone marrow derived mesenchymal stem cells. J Orthop Res. 2012;30(4):634-42 This study indicates the similarity of MSCs extracted from peripheral blood to bone marrowderived MSCs.

90. Horn P, Bork S, Diehlmann A, Walenda T, Eckstein V, Ho A, et al. Isolation of human mesenchymal stromal cells is more efficient by red blood cell lysis. Cytotherapy. 2008;10(7):676-85.

91. Horn P, Bork S, Wagner W. Standardized isolation of human mesenchymal stromal cells with red blood cell lysis. Methods Mol Biol. 2011;698:23-35.

92. Li H, Ghazanfari R, Zacharaki D, Lim HC, Scheding S. Isolation and characterization of primary bone marrow mesenchymal stromal cells. Ann N Y Acad Sci. 2016;1370(1):109-18.

93. Lawless C, Wang C, Jurk D, Merz A, von Zglinicki T, Passos JF. Quantitative assessment of markers for cell senescence. Exp Gerontol. 2010;45(10):772-8.

94. Russell AL, Lefavor R, Durand N, Glover L, Zubair AC. Modifiers of mesenchymal stem cell quantity and quality. Transfusion. 2018;58(6):1434 40.

95. Churchman SM, Boxall SA, McGonagle D, Jones EA. Predicting the remaining lifespan and cultivation-related loss of osteogenic capacity of bone marrow multipotential stromal cells applicable across a broad donor age range. Stem Cells Int. 2017;2017.

96. Yang YHK, Ogando CR, Wang See C, Chang TY, Barabino GA. Changes in phenotype and differentiation potential of human mesenchymal stem cells aging in vitro. Stem Cell Res Ther. 2018;9(1): $1-14$.

97. Mohamed-Ahmed S, et al. Adipose-derived and bone marrow mesenchymal stem cells: a donor-matched comparison. Stem Cell Res Ther. 2018;9(1):168.

98. Adamzyk C, et al. Different culture media affect proliferation, surface epitope expression, and differentiation of ovine MSC. Stem Cells Int. 2013;2013.

99. Czapla J, et al. The effect of culture media on large-scale expansion and characteristic of adipose tissue-derived mesenchymal stromal cells. Stem Cell Res Ther. 2019;10(1):1-11.

100. Fu W-L, et al. Proliferation and apoptosis property of mesenchymal stem cells derived from peripheral blood under the culture conditions of hypoxia and serum deprivation. Chin Med J. 2011;124(23):3959-67.

101. Tondreau T, Meuleman N, Delforge A, Dejeneffe M, Leroy R, Massy M, et al. Mesenchymal stem cells derived from CD133positive cells in mobilized peripheral blood and cord blood: proliferation, Oct4 expression, and plasticity. Stem Cells. 2005;23(8): $1105-12$.

102. Zheng Y-H, Xiong W, Su K, Kuang S-J, Zhang Z-G. Multilineage differentiation of human bone marrow mesenchymal stem cells in vitro and in vivo. Exp Ther Med. 2013;5(6):1576-80.

103. Schmelzer E, McKeel DT, Gerlach JC. Characterization of human mesenchymal stem cells from different tissues and their membrane encasement for prospective transplantation therapies. Biomed Res Int. 2019;2019:6376271.

104. Baksh D, Yao R, Tuan RS. Comparison of proliferative and multilineage differentiation potential of human mesenchymal stem cells derived from umbilical cord and bone marrow. Stem Cells. 2007;25(6):1384-92.

105. Guneta V, Tan NS, Chan SKJ, Tanavde V, Lim TC, Wong TCM, et al. Comparative study of adipose-derived stem cells and bone marrow-derived stem cells in similar microenvironmental conditions. Exp Cell Res. Nov. 2016;348(2):155-64.

106. Kim J, Shin JM, Jeon YJ, Chung HM, Chae J-I. Proteomic validation of multifunctional molecules in mesenchymal stem cells derived from human bone marrow, umbilical cord blood and peripheral blood. PLoS One. 2012;7(5):e32350.

107. Al-Nbaheen M, et al. Human stromal (mesenchymal) stem cells from bone marrow, adipose tissue and skin exhibit differences in molecular phenotype and differentiation potential. Stem cell Rev reports. 2013;9(1):32-43.

108. Gamblin A-L, Brennan MA, Renaud A, Yagita H, Lézot F, Heymann D, et al. Bone tissue formation with human mesenchymal stem cells and biphasic calcium phosphate ceramics: the local implication of osteoclasts and macrophages. Biomaterials. 2014;35(36):9660-7.

109. Granero-Moltó F, Weis JA, Miga MI, Landis B, Myers TJ, O'Rear L, et al. Regenerative effects of transplanted mesenchymal stem cells in fracture healing. Stem Cells. 2009;27(8):1887-98.

110. Huang S, Xu L, Zhang Y, Sun Y, Li G. Systemic and local administration of allogeneic bone marrow-derived mesenchymal stem cells promotes fracture healing in rats. Cell Transplant. 2015;24(12):2643-55.

111. Furuta T, Miyaki S, Ishitobi H, Ogura T, Kato Y, Kamei N, et al. Mesenchymal stem cell-derived exosomes promote fracture healing in a mouse model. Stem Cells Transl Med. 2016;5(12): 1620-30.

112. Watson L, Elliman SJ, Coleman CM. From isolation to implantation: a concise review of mesenchymal stem cell therapy in bone fracture repair. Stem Cell Res. Ther. 2014;5(2):51.

113. Wan C, He Q, Li G. Allogenic peripheral blood derived mesenchymal stem cells (MSCs) enhance bone regeneration in rabbit ulna critical-sized bone defect model. J Orthop Res. 2006;24(4): $610-8$.

114. Li S, Huang KJ, Wu JC, Hu MS, Sanyal M, Hu M, et al. Peripheral blood-derived mesenchymal stem cells: candidate cells responsible for healing critical-sized calvarial bone defects. Stem Cells Transl Med. 2015;4(4):359-68.

115. Boukhechba F, Balaguer T, Michiels JF, Ackermann K, Quincey $\mathrm{D}$, Bouler JM, et al. Human primary osteocyte differentiation in a 3D culture system. J Bone Miner Res. 2009;24(11):1927-35.

116. Robin M, Almeida C, Azaïs T, Haye B, Illoul C, Lesieur J, et al. Involvement of $3 \mathrm{D}$ osteoblast migration and bone apatite during in vitro early osteocytogenesis. Bone. 2016;88:146-56.

117. Kogawa M, Wijenayaka AR, Ormsby RT, Thomas GP, Anderson $\mathrm{PH}$, Bonewald LF, et al. Sclerostin regulates release of bone mineral by osteocytes by induction of carbonic anhydrase 2 . J Bone Miner Res. 2013;28(12):2436-48.

118. Sun Q, Choudhary S, Mannion C, Kissin Y, Zilberberg J, Lee WY. Ex vivo construction of human primary 3D-networked osteocytes. Bone. Dec. 2017;105:245-52.

119. Sun Q, Gu Y, Zhang W, Dziopa L, Zilberberg J, Lee W. Ex vivo $3 \mathrm{D}$ osteocyte network construction with primary murine bone cells. Bone Res. 2015;3(1):15026.

120. Hikita A, Iimura T, Oshima Y, Saitou T, Yamamoto S, Imamura $\mathrm{T}$. Analyses of bone modeling and remodeling using in vitro reconstitution system with two-photon microscopy. Bone. 2015;76: $5-17$.

121. Iordachescu A, et al. An in vitro model for the development of mature bone containing an osteocyte network. Adv Biosyst. 2018;2(2).

122. Thompson WR, Uzer G, Brobst KE, Xie Z, Sen B, Yen SS, et al. Osteocyte specific responses to soluble and mechanical stimuli in a stem cell derived culture model. Sci Rep. 2015;5:11049.

123. Liu C, Zhang X, Wu M, You L. Mechanical loading up-regulates early remodeling signals from osteocytes subjected to physical damage. J Biomech. 2015;48(16):4221-8.

124. Rossi L, Challen GA, Sirin O, Lin KK, Goodell MA. Hematopoietic stem cell characterization and isolation. Methods Mol Biol. 2011;750:47-59.

125. A. P. Ng and W. S. Alexander, Haematopoietic stem cells : past, present and future, Cell death Discov, vol. 3, pp. 2-5, 2017.

126. Walasek MA, van Os R, de Haan G. Hematopoietic stem cell expansion: challenges and opportunities. Ann N Y Acad Sci. 2012;1266(1):138-50. 
127. Abkowitz JL, Catlin SN, McCallie MT, Guttorp P. Evidence that the number of hematopoietic stem cells per animal is conserved in mammals. Blood. 2002;100(7):2665-7.

128. Farrell TL, McGuire TR, Bilek LD, Brusnahan SK, Jackson JD, Lane JT, et al. Changes in the frequencies of human hematopoietic stem and progenitor cells with age and site. Exp Hematol. 2014;42(2):146-54.

129. Rebolj K, Veber M, Drobnic M, Malicev E. Hematopoietic stem cell and mesenchymal stem cell population size in bone marrow samples depends on patient's age and harvesting technique. Cytotechnology. 2018;70(6):1575-83.

130. Pei X. Who is hematopoietic stem cell: CD34+ or CD34-? Int J Hematol. 1999;70(4):213-5.

131. AbuSamra DB, Aleisa FA, al-Amoodi AS, Jalal Ahmed HM, Chin CJ, Abuelela AF, et al. Not just a marker: CD34 on human hematopoietic stem/progenitor cells dominates vascular selectin binding along with CD44. Blood Adv. 2017;1(27):2799-816.

132. Bujko K, Kucia M, Ratajczak J, Ratajczak MZ. Hematopoietic stem and progenitor cells (HSPCs), in. Stem cells. 2019:49-77.

133. Smith-Berdan S, Bercasio A, Rajendiran S, Forsberg EC. Viagra enables efficient, single-day hematopoietic stem cell mobilization. Stem Cell Reports. 2019;13(5):787-92.

134. Pusic I, Jiang SY, Landua S, Uy GL, Rettig MP, Cashen AF, et al. Impact of mobilization and remobilization strategies on achieving sufficient stem cell yields for autologous transplantation. Biol Blood Marrow Transplant. 2008;14(9):1045-56.

135. De Bruyn C, Delforge A, Lagneaux L, Bron D. Characterization of CD34+ subsets derived from bone marrow, umbilical cord blood and mobilized peripheral blood after stem cell factor and interleukin 3 stimulation. Bone Marrow Transplant. 2000;25(4): 377-83.

136. Schmid FV, Kleinhans C, Schmid FF, Kluger PJ. Osteoclast formation within a human co-culture system on bone material as an in vitro model for bone remodeling processes. Funct Morphol Kinesiol. 2018;3(17)

137. Bernhardt A, Thieme S, Domaschke H, Springer A, Rosen-Wolff A, Gelinsky M. Crosstalk of osteoblast and osteoclast precursors on mineralized collagen-towards an in vitro model for bone remodeling. J Biomed Mater Res A. 2010;95(3):848-56.

138. Friederichs RJ, Brooks RA, Ueda M, Best SM. In vitro osteoclast formation and resorption of silicon-substituted hydroxyapatite ceramics. J Biomed Mater Res Part A. 2015;103(10):3312-22.

139. Quinn JMW, Neale S, Fujikawa Y, McGee JOD, Athanasou NA. Human osteoclast formation from blood monocytes, peritoneal macrophages, and bone marrow cells. Calcif Tissue Int. 1998;62(6):527-31.

140. Takahashi N, Kukita T, MacDonald BR, Bird A, Mundy GR, McManus LM, et al. Osteoclast-like cells form in long-term human bone marrow but not in peripheral blood cultures. J Clin Invest. Feb. 1989;83(2):543-50.

141. Yi L, Li Z, Jiang H, Cao Z, Liu J, Zhang X. Gene modification of transforming growth factor $\beta$ (TGF- $\beta$ ) and interleukin 10 (IL-10) in suppressing $\mathrm{Mt}$ Sonicate induced osteoclast formation and bone absorption. Med Sci Monit. Jul. 2018;24:5200-7.

142. Kleiveland CR. Peripheral blood mononuclear cells. In: Verhoeckx K, Cotter P, López-Expósito I, Kleiveland C, Lea T, Mackie A, Requena T, Swiatecka D, Wichers H, editors. The impact of food bioactives on health: in vitro and ex vivo models. Cham: Springer International Publishing; 2015. p. 161-7.

143.• Kylmäoja E, et al. Peripheral blood monocytes show increased osteoclast differentiation potential compared to bone marrow monocytes. Heliyon. 2018;4(9) This study indicates the importance of medium composition of osteoclast progenitor cells differentiation isolated from bone marrow and peripheral blood.
144. Yazid MD, Zainal Ariffin SH, Senafi S, Zainal Ariffin Z, Wahab RMA. Stem cell heterogeneity of mononucleated cells from murine peripheral blood: molecular analysis. Sci World J. 2011;11: 2150-9.

145. Schulze S, Wehrum D, Dieter P, Hempel U. A supplement-free osteoclast-osteoblast co-culture for pre-clinical application. J Cell Physiol. Jun. 2018;233(6):4391-400.

146. Henriksen K, Karsdal MA, Taylor A, Tosh D, Coxon FP. Generation of human osteoclasts from peripheral blood. Methods Mol Biol. 2012;816:159-75.

147. Reitsma MJ, Lee BR, Uchida N. Method for purification of human hematopoietic stem cells by flow cytometry. Methods Mol Med. 2002;63:59-77.

148. Tripathi $\mathrm{H}$, et al. Isolation methods for human CD34 subsets using fluorescent and magnetic activated cell sorting: an in vivo comparative study. Stem Cell Rev. Reports. 2020.

149. Ng YY, Baert MRM, de Haas EFE, Pike-Overzet K, Staal FJT. Isolation of human and mouse hematopoietic stem cells. Methods Mol Biol. 2009;506:13-21.

150. Spence G, Patel N, Brooks R, Bonfield W, Rushton N. Osteoclastogenesis on hydroxyapatite ceramics: the effect of carbonate substitution. J Biomed Mater Res A. Mar. 2010;92(4): 1292-300

151. Papadimitropoulos A, et al. A 3D in vitro bone organ model using human progenitor cells. Eur Cells Mater. 2011;21:445-58.

152. Rossi E, Mracsko E, Papadimitropoulos A, Allafi N, Reinhardt D, Mehrkens A, et al. An in vitro bone model to investigate the role of triggering receptor expressed on myeloid cells- 2 in bone homeostasis. Tissue Eng Part C Methods. 2018;24(7):391-8.

153. Deguchi T, Alanne MH, Fazeli E, Fagerlund KM, Pennanen P, Lehenkari $\mathrm{P}$, et al. In vitro model of bone to facilitate measurement of adhesion forces and super-resolution imaging of osteoclasts. Sci Rep. 2016;6:22585.

154. Tajer P, Pike-Overzet K, Arias S, Havenga M, Staal F. Ex vivo expansion of hematopoietic stem cells for therapeutic purposes: lessons from development and the niche. Cells. 2019;8(2):169.

155. Zhang Y, Gao Y. Novel chemical attempts at ex vivo hematopoietic stem cell expansion. Int J Hematol. 2016;103(5):519-29.

156. Wilkinson AC, Ishida R, Kikuchi M, Sudo K, Morita M, Crisostomo RV, et al. Long-term ex vivo haematopoietic-stemcell expansion allows nonconditioned transplantation. Nature. 2019;571(7763):117-21.

157. Lari R, Kitchener PD, Hamilton JA. The proliferative human monocyte subpopulation contains osteoclast precursors. Arthritis Res Ther. 2009;11(1):R23.

158. Ohta M, Okabe T, Ozawa K, Urabe A, Takaku F. $1 \alpha, 25$ Dihydroxy vitamin D3 (calcitriol) stimulates proliferation of human circulating monocytes in vitro. FEBS Lett. 1985;185(1):9-13.

159. Eischen A, Vincent F, Bergerat JP, Louis B, Faradji A, Bohbot A, et al. Long term cultures of human monocytes in vitro impact of GM-CSF on survival and differentiation. J Immunol Methods. 1991;143(2):209-21.

160. Ohta M, Ozawa K, Okabe T, Urabe A, Takaku F. Induction of proliferation of human circulating monocytes in vitro by lectininduced factor(s) from lymphocytes. Biochem Biophys Res Commun. 1985;126(2):705-11.

161. Finnin M, Hamilton JA, Moss ST. Characterization of a CSFinduced proliferating subpopulation of human peripheral blood monocytes by surface marker expression and cytokine production. J Leukoc Biol. 1999;66(6):953-60.

162. Pardali E, Schmitz T, Borgscheiper A, Iking J, Stegger L, Waltenberger J. Cryopreservation of primary human monocytes does not negatively affect their functionality or their ability to be labelled with radionuclides: basis for molecular imaging and cell therapy. EJNMMI Res. 2016;6(1):77. 
163. Van Der Meulen FW, Reiss M, Stricker EAM, Van Elven E, Von Dem Borne AEGK. Cryopreservation of human monocytes. Cryobiology. 1981;18(4):337-43.

164. Utsugi T, Brown D, Nii A, Fidler IJ. Frozen-thawed human blood monocytes respond reproducibly to activation stimuli: implications for screening of BRMs. Biotherapy. 1992;5(4):301-8.

165. Berz D, McCormack EM, Winer ES, Colvin GA, Quesenberry PJ. Cryopreservation of hematopoietic stem cells. Am J Hematol. 2007;82(6):463-72.
166. Flanagan AM, Massey HM. Generating human osteoclasts in vitro from bone marrow and peripheral blood. Methods Mol. Med. 2003;80:113-28.

167. Merrild DMH, et al. Pit- and trench-forming osteoclasts: a distinction that matters. Bone Res. 2015;3(1):15032.

Publisher's Note Springer Nature remains neutral with regard to jurisdictional claims in published maps and institutional affiliations. 